\title{
First steps towards the conservation of the microendemic Patagonian frog Atelognathus nitoi
}

\author{
Carmen Úbeda, Horacio Zagarese, Mónica Diaz and Fernando Pedrozo
}

\begin{abstract}
Atelognathus nitoi is a microendemic leptodactylid frog restricted to the area surrounding the pond Laguna Verde in the Nahuel Huapi National Reserve, north-west Patagonia, Argentina. Its habitat is potentially threatened by a number of anthropogenic and natural factors. The aim of this study was to obtain basic knowledge of the biology and habitat of the species, which would be useful for selecting management measures to ensure its conservation. The area was surveyed during all four seasons in 1996 and 1997 and Laguna Verde was sampled intensively in winter and in summer. Atelognathus nitoi is distributed patchily. The preferred microhabitats of adults and juveniles are the most humid areas of the forest. Reproduction and larval development occurs only in lentic environments. Laguna Verde is the only known permanent water-
\end{abstract}

body suitable for reproduction every year. During rainy years reproduction can also take place in temporary ponds. Action towards the conservation of $A$. nitoi should be aimed at preserving both the terrestrial and aquatic habitats. Laguna Verde appears to be a key site for the $A$. nitoi source population and plays an essential part in the conservation of this species. In terrestrial habitats it is vital to preserve the heterogeneity of the lower strata in the forest. The knowledge gained through this study has allowed the authors to suggest protective measures to mitigate or eliminate the impact of certain stressors on the ecology of the species.

Keywords Anura, Atelognathus nitoi, conservation biology, Leptodactylidae, Patagonia.

\section{Introduction}

Amphibians are sensitive bioindicators of the health of the environment because of their permeable skins, biphasic life history, pattern of embryonic development, population biology, site fidelity and the complexity of their interactions in communities and ecosystems (Wake \& Morowitz, 1991; Blaustein et al., 1994). Many reports during the past decade have warned of the decline of amphibian populations around the world. Among the potential causes of the decline are the destruction and fragmentation of habitats, chemical pollution, increases in levels of solar ultraviolet radiation and the introduction of exotic species (Wake \& Morowitz, 1991; Blaustein \& Wake, 1995).

The frog genus Atelognathus is restricted to Patagonia and includes seven species, all of which are endemic to areas of various sizes. Six are distributed to the east of the Andes mountain range in Argentine Patagonia

\footnotetext{
Carmen Úbeda (corresponding author) and Horacio Zagarese, Mónica Dlaz and Fernando Pedrozo Centro Regional Bariloche, Universidad Nacional del Comahue, Unidad Postal Universidad, 8400-San Carlos de Bariloche, Argentina.

E-mail: cubeda@bariloche.com.ar
}

(provinces of Neuquén, Río Negro and Chubut) and one is found on Wellington Island, Chile (Frost, 1985; Duellman, 1993). Atelognathus nitoi Barrio, 1973, is a medium-sized (45 mm) leptodactylid frog (Plate 1), endemic to the area surrounding a small pond, Laguna Verde, in the Nahuel Huapi National Reserve in northwest Patagonia, Argentina. It was discovered recently (Barrio, 1973) and has received little study (Christie, 1984; Úbeda et al., 1994; Basso \& Úbeda, 1997). Its basic biology is as yet unknown. Its status categories are summarized in Table 1.

Although Laguna Verde is part of a national reserve with a long tradition in conservation, the habitat is potentially threatened by a number of anthropogenic and natural factors including fires, increased levels of ultraviolet radiation, recreational activities and fuelwood gathering for a nearby mountain lodge. In fact, the whole area was in danger of destruction from the intense fires that occurred in January 1996 and affected a large part of the adjacent forest.

The aim of this study was to obtain a basic knowledge of the biology and habitat of the species, which would be useful for selecting management measures to ensure its conservation. Our ultimate purpose is to help develop policies to protect the natural habitat of the species. To this end, our aims were to: 


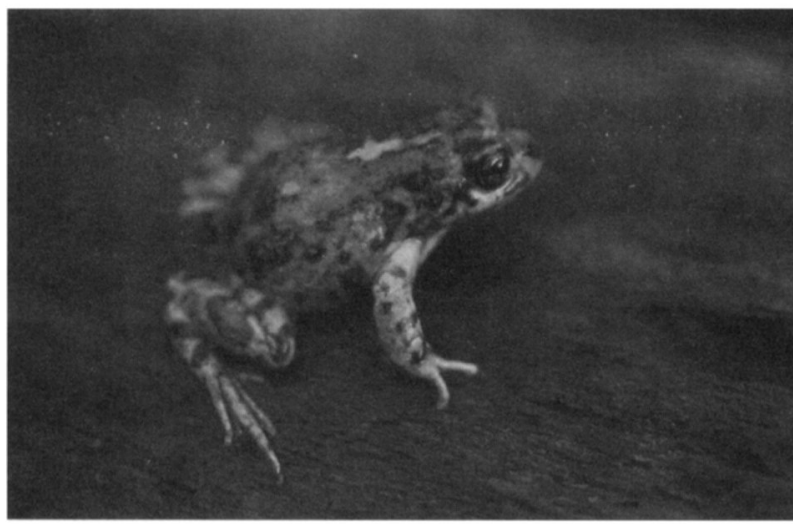

Plate 1 The Atelognathus nitoi adult has a stout body and short legs, webbed toes, smooth skin on dorsum and belly, loose baggy skin on sides; is brownish or greyish on the back, with irregular dark spots; and a smooth, immaculate, whitish belly.

- Characterize the terrestrial and aquatic habitats, and microhabitats, of the adult, juvenile and larval stages.

- Obtain basic information on the biology of the species, such as reproductive period, duration of the larval stage and timing of metamorphosis.

- Identify potential conflicts or impacts of human activities occurring in the area and assess their significance for the species.

\section{Materials and methods}

\section{Study area}

In the area surrounding Laguna Verde on Cerro Challhuaco, the terrain is mainly mountainous, with some gentle slopes that allow flood meadows (mallines) and temporary aquatic environments to form in depressions. The climate is temperate (mean temperature $5-8^{\circ} \mathrm{C}$ ) and rainy (mean annual precipitation $1700 \mathrm{~mm}$; Barros et al., 1983). Most rainfall occurs during the winter, from May to August. In winter, the area is covered by a mantle of snow and the surfaces of aquatic habitats freeze. The area is part of the Decidu- ous Forest district of the Subantarctic province (Cabrera \& Willink, 1980). The vegetation is pure austral beech Nothofagus pumilio deciduous forest. The underbrush is relatively open, with low bushes.

\section{Sampling and survey}

\section{Study area}

The area was prospected from the air and the land surveyed on periodic visits during all four seasons in 1996 and 1997. Ninety-five ha were surveyed for the occurrence of $A$. nito in terrestrial and aquatic habitats between 1300 and $1750 \mathrm{~m}$ above sea level, following roughly parallel transects about $30 \mathrm{~m}$ apart (Fig. 1).

Excluding areas that are unsuitable for amphibian use, the following habitats were distinguished:

Terrestrial: high altitude austral beech thicket; austral beech forest.

Aquatic: stream sources; flood meadows (mallines); bogs; permanent ponds; temporary ponds; streams; and stream banks. The Laguna Verde pond was selected for an intensive study.

From each site where the species was found, information was recorded for the description of habitats and microhabitats, following Heyer et al. (1994). For terrestrial habitats the data recorded were: slope and topography; description of the vegetation (canopy cover, plant type); soil type; horizontal and vertical position; substratum type; per cent humidity and temperature of the site and the environment. For aquatic and wetland habitats we noted: type of waterbody (permanent or temporary); type of vegetation; type of bottom; degree of insolation; $\mathrm{pH}$; temperature; and associated biota.

Each $A$. nitoi observation was recorded individually. The following information was taken for each specimen encountered during the survey: size (snout-vent length); sex; and evidence of recent metamorphosis.

In order to obtain a rough estimate of the $A$. nitoi population, one habitat patch was sampled when the concentration of individuals was at its maximum, using the patch sampling method in Heyer et al. (1994).

Table 1 Legal and status categories of Atelognathus nitoi given by different national and international organizations

\begin{tabular}{lll}
\hline $\begin{array}{l}\text { Status and legal } \\
\text { categories }\end{array}$ & Organization & Reference \\
\hline $\begin{array}{l}\text { Vulnerable } \\
\text { Vulnerable }\end{array}$ & IUCN-The World Conservation Union & IUCN (1996) \\
Vulnerable & Secretaría de Agricultura y Ganadería, Argentina & Secretaría de Agricultura y Ganadería (1983) \\
$\begin{array}{l}\text { Protected species } \\
\text { Special value species }\end{array}$ & Dirección Nacional de Fauna y Flora Silvestres, Argentina & Úbeda \& Grigera (1995) \\
& Subdirección de Fauna, Provincia de Río Negro, Argentina & Provincia de Río Negro (1993) \\
& & Administración de Parques Nacionales (1994) \\
\hline
\end{tabular}


Fig. 1 Study area in the Nahuel Huapi National Reserve. Shading represents surveyed area. House symbol represents Neumeyer lodge. Dotted line represents the access dirt road.

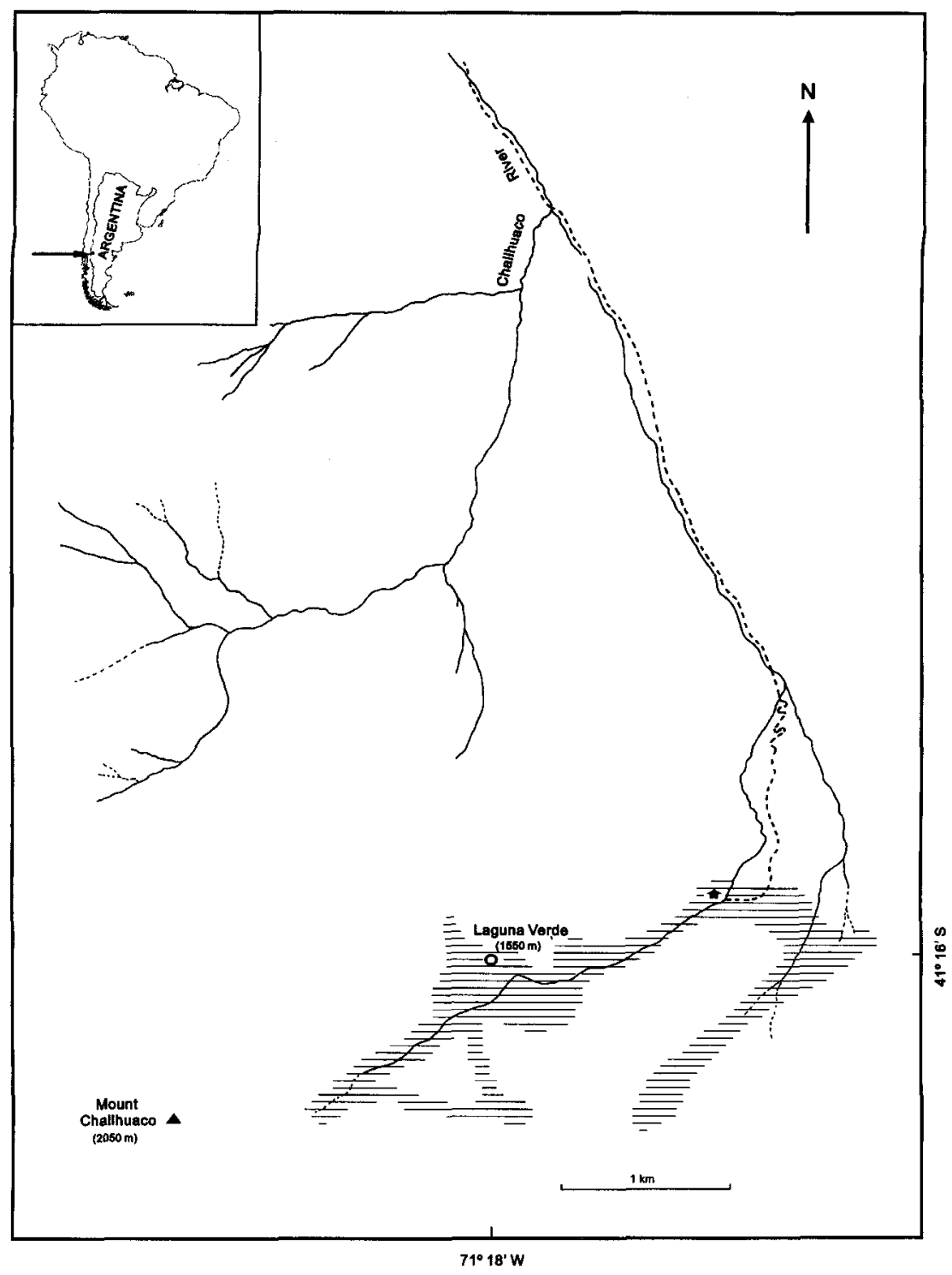

Laguna Verde sampling

Laguna Verde was sampled intensively twice: in winter (10 September 1996) and late summer (14 March 1997). The following variables were measured in the field: $\mathrm{pH}$ ( $\mathrm{pH}$ meter); conductivity (conductimeter); dissolved oxygen (ISY oxygen meter); temperature (digital thermometer); and natural radiation profiles (IL-1700 radiometer with UV-A, UV-B and PAR submersible sensors). Water samples were taken to determine nutrient and chlorophyll concentrations, and species and biomass of phytoplankton and zooplankton. The chlorophyll and nutrient samples were analysed using standard methods (APHA, 1985).

Phytoplankton samples were taken at depth intervals of $1 \mathrm{~m}$ in the limnetic area of the pond, using a 2-L Van Dorn bottle. Samples were fixed using acetic lugol solution and counted under an inverted microscope following Utermohl's method. To estimate biomass, cell volume for each species was estimated by comparing cell shapes with geometric shapes (Nauwerk, 1963). Biomass was then expressed as fresh algal weight, considering phytoplankton density $=1$ and the relation $10^{6} \mu \mathrm{m}^{3}=1 \mu \mathrm{g}$, following the Goldman criterion (in Trevisan, 1979).

Zooplankton samples were taken at depth intervals of $1 \mathrm{~m}$ with a Van Dorn bottle. They were filtered through a $55 \mu \mathrm{m}$ mesh and fixed in 4 per cent formalin. Samples were counted under a dissecting scope. 


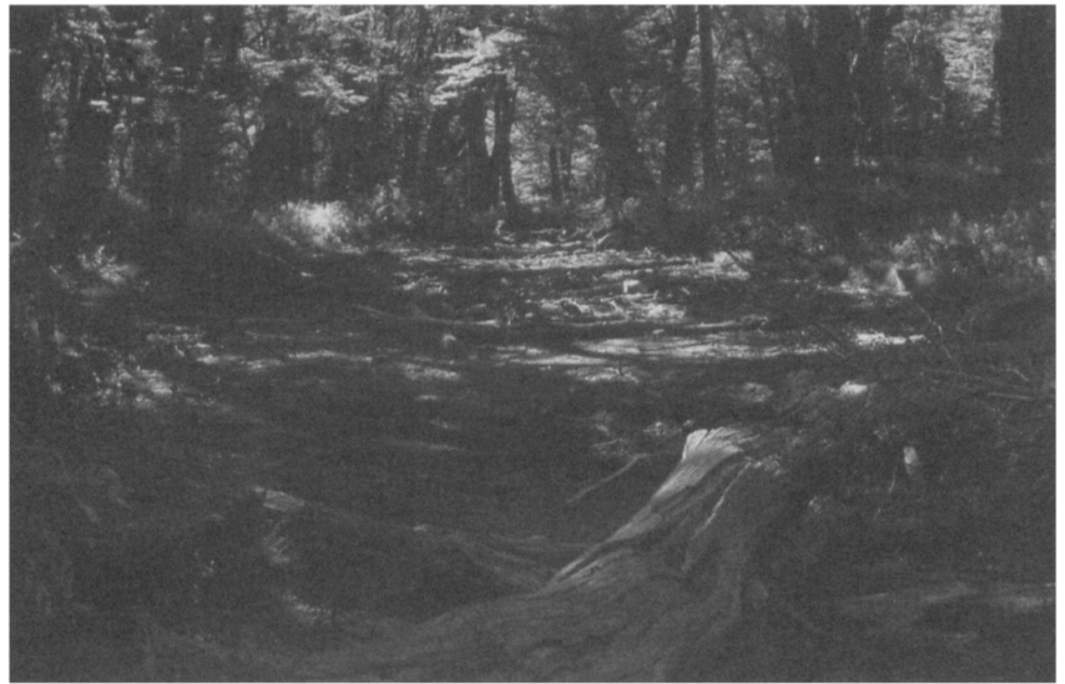

Plate 2 Terrestrial habitat of Atelognathus nitoi: humid areas in the forest, with fallen logs, branches and bark.

\section{Results}

\section{Terrestrial habitats}

Adults and juveniles inhabit an austral beech Nothofagus pumilio deciduous high-altitude forest, which has a low, sparse understorey comprising shrubs (Berberis pearcei, Maytenus disticha, Myoschilus oblongum, Ribes magellanicum, Chiliothrichium rosmarinifolium) and herbaceous plants (Valeriana sp., Alstroemeria aurantiaca, Acaena argentea, Vicia nigricans, Geum magellanicum). Forest litter and fallen branches are abundant. At higher altitudes, the trees are smaller and the forest becomes a thicket. There are humid microenvironments in stream valleys, with a herbaceous stratum including many mosses, ferns (Blechnum penna-marina, Rumohra adiantiformis) and other herbs (Ourisia sp.). In winter the ground is covered with snow up to $1 \mathrm{~m}$ deep.
Atelognathus nitoi is distributed patchily. The microhabitats where concentrations of adults and juveniles are found are the most humid areas of the forest, with shade or semi-shade, and an abundance of fallen logs, branches and bark, which serve as refugia (Plate 2 ). In the 95 ha that were surveyed, A. nito $i$ was found in nine patches between 1300 and $1550 \mathrm{~m}$ a.s.l. The total area of these patches was estimated to be $c .2000 \mathrm{sq} \mathrm{m}$. Extrapolating from the density in one intensively sampled patch, the estimated minimum population is about 750 individuals.

\section{Aquatic habitats}

Laguna Verde

Laguna Verde $(1550 \mathrm{~m}$ a.s.l.) is the only permanent body of water in the area where $A$. nito $i$ tadpoles have been seen every year (Plate 3 ). The pond is about $80 \mathrm{~m}$

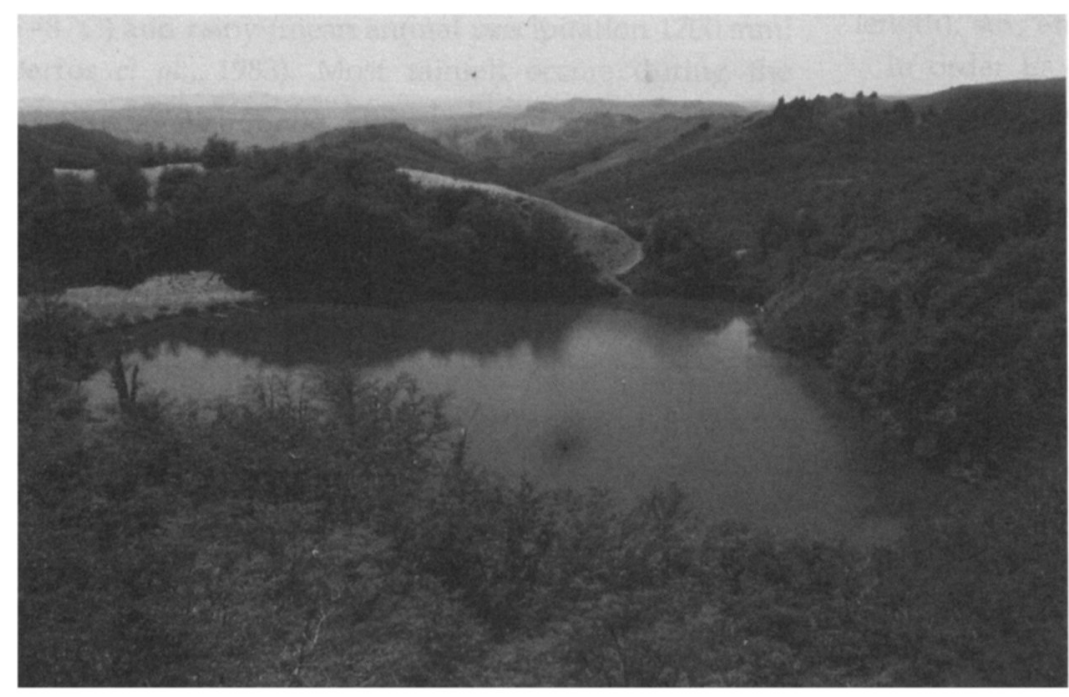

Plate 3 View of Laguna Verde and surrounding austral beech (Nothofagus pumilio) forest, Cerro Challhuaco, Nahuel Huapi National Reserve. 
Plate 4 A temporary aquatic environment occasionally used by Atelognathus nitoi for reproduction.

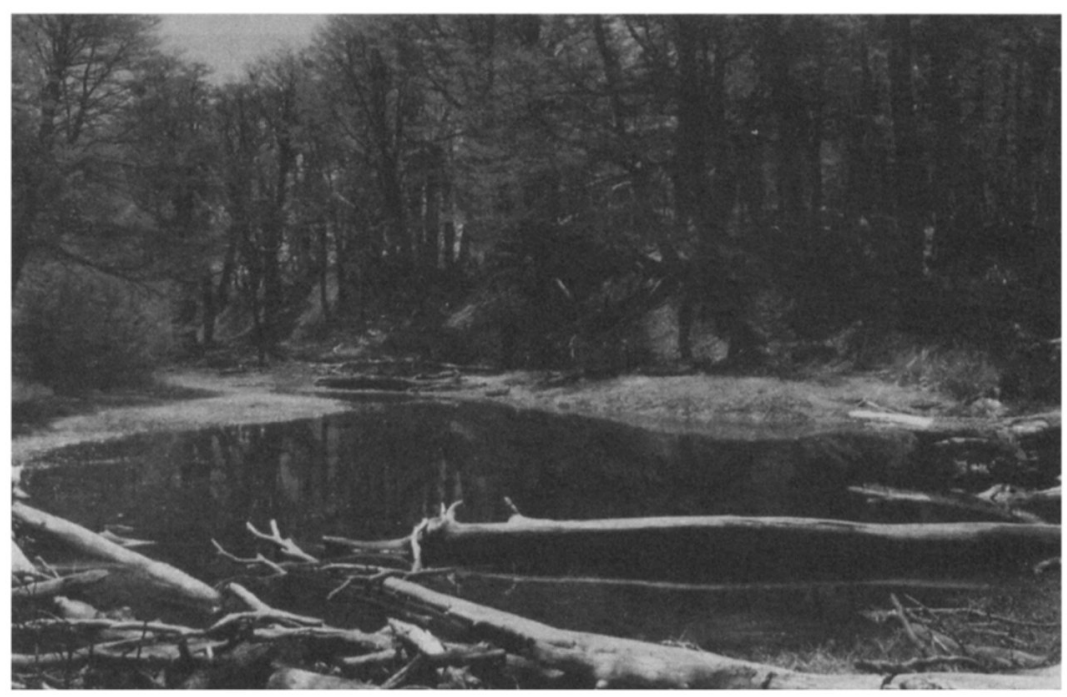

in diameter and 5-6 $\mathrm{m}$ deep. Its level fluctuates by about $1 \mathrm{~m}$, depending on precipitation and snowmelt. For a period of 4-6 months each year, the pond floods, feeding another small, nearby pond. When the level falls a narrow sandy beach, stony in parts, is exposed. There is very little vegetation on the shoreline: Gunnera magellanica, Veronica sp., bryophytes, and a few grasses and herbs. During winter, a $30-\mathrm{cm}$ layer of ice forms on the pond's surface.

There is high attenuation of solar radiation in the pond so that in spite of its shallowness there is an aphotic zone. During periods of stratification the aphotic zone causes dissolved oxygen to decrease in the hypolimnion. The pond bottom is covered with a layer of suspended organic matter made up of faecal pellets, and remains of animals and algae at various stages of decomposition (Fig. 2). These characteristics are a direct

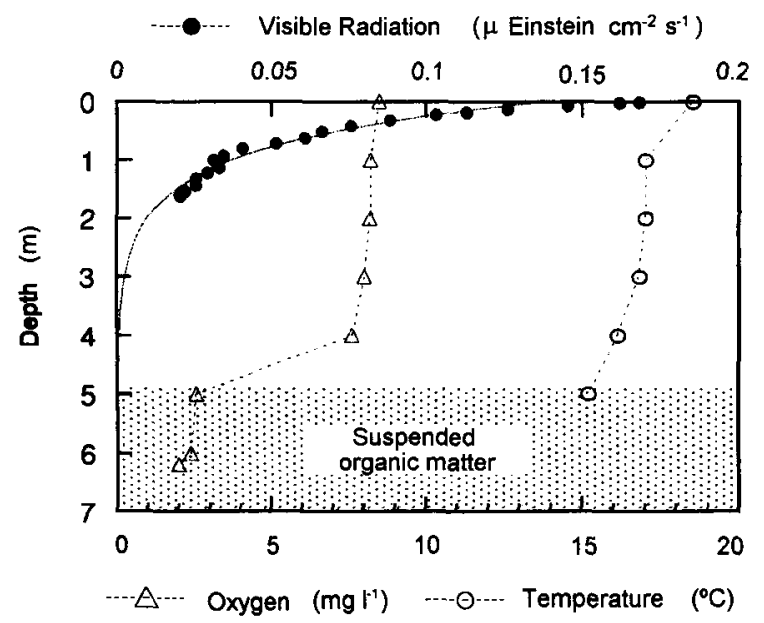

Fig. 2 Radiation, oxygen and temperature vertical profiles in Laguna Verde on a sunny summer day (14 March 1997). consequence of the pond's depth and high productivity as a result of the higher nutrient concentrations than in most other mountain waterbodies in the area.

Laguna Verde is mesotrophic (Chla $=9.7 \mu \mathrm{g} \mathrm{L}^{-1}$ ), as shown by phytoplankton density and biomass values (Vollenweider, 1968; Wetzel, 1975) as well as dominant phytoplankton species and seasonal succession (Reynolds, 1984). Both phytoplankton density and biomass were minimum in superficial winter samples $\left(1.028 \times 10^{6}\right.$ cells $\left.\mathrm{m}^{-3}, 200 \mathrm{mg} \mathrm{m}^{-3}\right)$ and maximum in summer bottom samples $\left(28.644 \times 10^{6}\right.$ cells $\mathrm{m}^{-3}$, $5400 \mathrm{mg} \mathrm{m}^{-3}$ ). Species richness is similar to that of other altitudinal ponds in the zone, all of which have low diversity compared with shallow lentic environments at lower altitudes (Diaz, 1994). As a result of the high phytoplankton biomass, incident light is rapidly attenuated in the water column. This promotes the formation of an anoxic hypolimnion during periods of weak vertical mixing (i.e. calm weather, ice cover period; Fig. 2).

Zooplankton composition also showed very low diversity. The community is made up of one calanoid copepod, one cyclopoid copepod, two cladocerans and two rotifers. The dominant species is the calanoid copepod Boeckella gracilipes, which is very common in similar environments at lower altitudes, although unusual in the high-altitude lakes in the area. It is very sensitive to UV radiation and its presence in Laguna Verde is probably due to the low transparency of the water. Most high altitude lakes in the area are much more transparent, and Boeckella gibbosa, more tolerant of high levels of UV radiation (Zagarese et al., 1997), is dominant in those.

Other temporary bodies of water

During rainy years (e.g. 1995 and 1997), A. nitoi has 


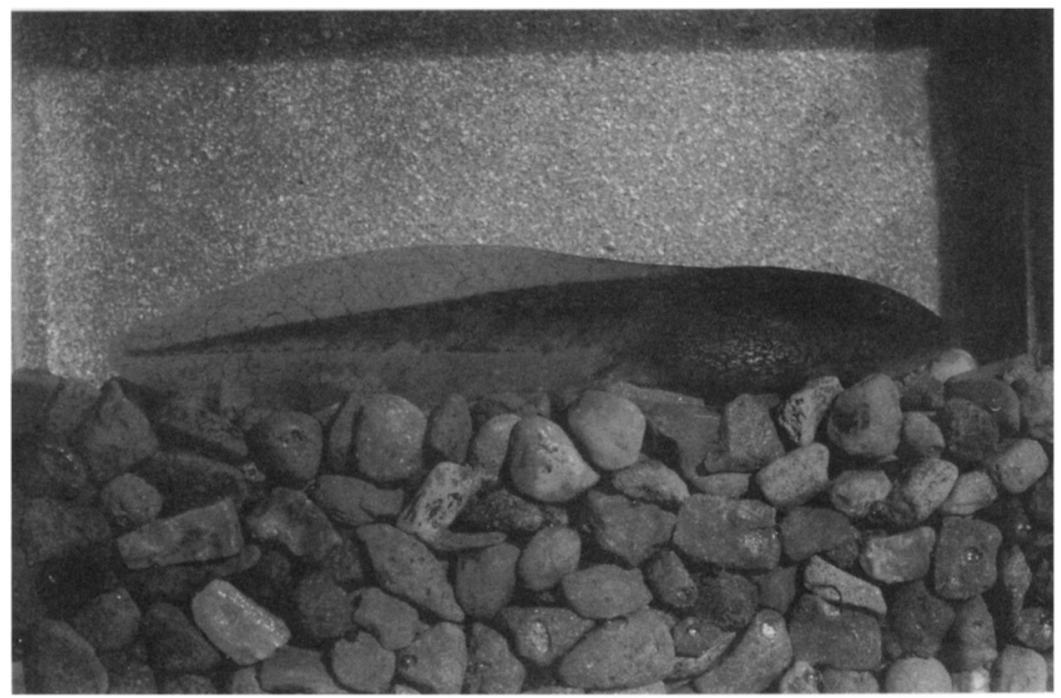

Plate 5 Atelognathus nitoi larva (lentic-benthic type).

been found to reproduce in temporary bodies of water (Plate 4), which have completely different limnological characteristics from Laguna Verde. The water in the temporary waterbodies comes from pluvial drainage and is rich in humic acids. The bed is rich in litter, fallen branches and logs. The most common algae are the palmeloid state of Chlamydomonas sp. and other Chloroccocales. The macrophyte Myriophyllum elatinoides sometimes grows in some of these environments. There are many copepods (Boeckella sp.) and amphipods (Hyalella sp.). When there are grasses on the shore, another leptodactylid frog (Pleurodema thaul) is also able to reproduce in these ponds. In these temporary ponds, UV is presumably attenuated very rapidly by the high level of dissolved organic carbon and/or phytoplankton blooms.

\section{Biological aspects}

Atelognathus nitoi reproduces in spring (middle to end of October), after snowmelt. Males have been heard calling from November to January. Reproduction and larval development occurs only in lentic environments. The larva belongs to the lentic-benthic morphotype (Basso \& Úbeda, 1997; Plate 5). Occasional observations of digestive content and faeces have shown that it feeds on planktonic algae (Staurastrum spp., Oocystis submarine, Dictyosphaerium pulchellum) and periphytic diatoms (Diploneis sp., Navicula spp., Cymbella spp.).

In Laguna Verde, the larvae can either complete their metamorphosis towards the end of summer, or remain as tadpoles until the following summer (December). Thus, the species has a dual survival strategy, with one period of juvenile recruitment at the end of summer and another at the beginning of the following summer.
In temporary environments, on the other hand, larvae must metamorphose before the environment dries up completely at the end of summer.

Recently hatched larvae ( $9 \mathrm{~mm}$ total length) swim near the shore in shallow water, while larger ones $(30-75 \mathrm{~mm})$ swim as deep as the environment allows. Immediately after metamorphosis, the juveniles (17$23 \mathrm{~mm}$ snout-vent length) remain near the body of water where they developed and then move into the forest as they grow.

\section{Discussion}

The known habitat of this microendemic frog spans only a few hectares around Laguna Verde in Cerro Challhuaco. Within this small area, the population is concentrated in habitat patches with a population size estimated to be in the order of 1000 individuals.

Amphibians are very dependent on their habitat, and we believe that the appropriate environmental conditions for $A$. nito $i$ are limited to this area. The question arises as to what environmental constraints determine the occurrence of the species. The adults, which are mostly restricted to terrestrial habitats, would be able to live in the many similar austral beech forests that exist in the region. Therefore, we suspect that the distribution of $A$. nitoi must be limited by the aquatic environments because of their role in reproduction and larval development. Our observations of the species's basic reproductive aspects points to lentic environments. Temporary environments, which do occur outside the species's distribution area, cannot ensure reproduction in dry years, and therefore could not determine the distribution of the species. So far, the only known permanent waterbody suitable for repro- 
duction every year is Laguna Verde. The two nearest permanent ponds are some $18 \mathrm{~km}$ away in a nearby unexplored valley. In addition, Laguna Verde appears to be the centre of the geographical distribution of $A$. nitoi. This pond has a number of features that make it unique and determinant for the occurrence of $A$. nitoi. The pond does not contain fish nor is it connected with other streams containing fish, and there are no aquatic carnivorous mammals or birds that could prey on $A$. nitoi. It does not contain macrophytes or marginal paludal vegetation that could favour other amphibian species that could eventually compete with $A$. nitoi. Laguna Verde has very high productivity, but lacks nuisance cyanophyceae or other filamentous algae. There is an important bottom layer of organic sediment, which contributes to the development of an anoxic hypolimnion. The occurrence of a UV-sensitive copepod species and the high attenuation of UV measured in situ, indicate that the environment is protected from damaging UV levels and constitutes a refuge for eggs and larvae of $A$. nitoi.

We believe that if habitats similar to Laguna Verde could be found in the region (which has not been fully surveyed), there should be good chances of discovering additional populations. Our future work will therefore be oriented towards an extensive survey of the surrounding area.

\section{Conservation and management}

Although $A$. nitoi's distribution area lies within a national protection unit (Nahuel Huapi National Reserve), the species's very small range is a matter of concern. There is no doubt that the survival of $A$. nito depends on the preservation of its natural habitat. Action towards its conservation should be aimed at preserving both the terrestrial environments necessary for juveniles and adults, and the aquatic environments necessary for reproduction and larval development.

Recreational activities in the area (hiking, skiing, recreational use of the pond and its shore, occasional swimming), fuelwood gathering for the nearby mountain lodge, and natural or intentional fires could seriously hamper $A$. nitoi's chances of survival

Laguna Verde seems to be the key aquatic environment for the $A$. nitoi population and plays an essential part in its conservation. Atelognathus nitoi tadpoles are the only vertebrates present in this pond. The species is safe from exotic salmonid and other native fishes, and illegal introduction of fishes into the pond could have catastrophic consequences, as has happened with the endemic frog A. patagonicus after the unauthorized introduction of perch Percichthys trucha in Laguna Blanca.
To ensure the conservation of $A$. nitoi, small temporary bodies of water that are used for reproduction during particularly rainy years should be protected from any kind of alteration.

In terrestrial habitats, it is vital to preserve the heterogeneity of the lower strata in the forest (logs, branches and bark on the ground), which provide the microhabitats that the species needs for refuge.

The knowledge gained through this study has allowed us to suggest protective measures to mitigate or eliminate the impact of certain stressors on the ecology of the species. Some have already been implemented by the National Park Administration, prioritizing the most critical areas for the species. Firstly, the trail from the mountain lodge (Refugio Neumeyer) to Laguna Verde (about an hour's walk) has been redesigned in an attempt to prevent the transit of visitors near temporary ponds and other areas frequented by $A$. nitoi. Secondly, the removal of logs from critical areas has been banned. Other measures to protect the pond shore and shallow waters will be implemented shortly. The measures include a ban on swimming, regulation of human activities on the beach and preservation of logs on the beach as refugia for $A$. nitoi.

\section{Acknowledgements}

We wish to thank: Pablo González, Pedro Temporetti, Barbara Tartarotti and Ricardo Ortubay for their help in the field; Javier Puntieri and Gustavo Baffico for the identification of plants and diatoms, respectively; Pedro Temporetti, Lucía Roselli and Patricia Satti for the laboratory analyses; and Chris Osburn for reading the manuscript. We would also like to thank Claudio Chehébar and Eduardo Ramilo from Administración de Parques Nacionales for permission and encouragement to study this species, Ronald Heyer and John Wilkinson for their invaluable improvements to an earlier version of the manuscript. This research was supported by Fauna \& Flora International (100 per cent Fund, Project Number 96/60/14) and by the International Foundation for Sciences (grant H-2325/2).

\section{References}

Administración de Parques Nacionales (1994) Resolución 180/ 94. Listas de Vertebrados de Valor Especial, pp. 5. Parques Nacionales, Reservas Nacionales y Monumentos Naturales Patagónicos, Buenos Aires.

APHA (1985) Standard Methods for the Examination of Water and Wastewater, 16th edn, pp. 1134. American Public Health Association, Washington. 
Barrio, A. (1973) Una nueva especie de Telmatobius (Anura, Leptodactylidae) procedente del dominio austral cordillerano argentino. Physis (Buenos Aires) Secc. C., 32(84), 207213.

Barros, V.R., Cordon, V.H., Moyano, C.L., Méndez, R.J., Forquera, J.C. \& Pizzio, O. (1983) Cartas de precipitación de la zona oeste de las provincials de Río Negro y Neuquén. Primera Contribución, pp. $28+$ figs. Universidad Nacional del Comahue and Centro Nacional Patagónico-CONICET, Cinco Saltos, Río Negro.

Basso, N.G. \& Úbeda, C.A. (1997) The tadpole of Atelognathus nitoi (Leptodactylidae: Telmatobiinae). Alytes, 15(3), 121126.

Blaustein, A.R. \& Wake, D.B. (1995) The puzzle of declining amphibian populations. Scientific American, April, 56-61.

Blaustein, A.R., Wake, D.B. \& Sousa, W.P. (1994) Amphibian declines: judging stability, persistence, and susceptibility of populations to local and global extinctions. Conservation Biology, 8(1), 60-71.

Cabrera, A.L. \& Willink, A. (1980) Biogeografia de América Latina, Segunda edición, Serie de Biología, Monografía No. 13, vi + pp. 117. Secretaría General de la OEA, Programa Regional de Desarrollo Cientifíco y Tecnológico, Washington, D.C.

Christie, M.I. (1984) Determinación de prioridades conservacionistas para la fauna de vertebrados patagónicos'. Revista del Museo Argentino de Ciencias Naturales, Zoología, 13(56), 535-544.

Diaz, M. (1994) Fitoplancton de lagos Andino-Patagónicos. Su relación con factores abióticos, pp. 178. PhD thesis, Facultad de Ciencias Exactas y Naturales, Universidad de Buenos Aires.

Duellman, W.E. (1993) Amphibian Species of the World: Additions and Corrections, Special Publication No. 21, i-iii, pp. 372. The University of Kansas, Museum of Natural History, Lawrence, KS, USA.

Frost, D.R. (1985) Amphibian Species of the World. A Taxonomic and Geographical Reference, pp. 732. Allen Press Inc. and The Association of Systematics Collections, Lawrence, KS, USA.

Heyer, W.R., Donnelly, M.A., McDiarmid, R.W., Hayek, L.A.C. \& Foster, M.S. (1994) Measuring and Monitoring Biological Diversity. Standard Methods for Amphibians, pp. 364. Smithsonian Institution Press, Washington and London.

IUCN (1996) 1996 IUCN Red List of Threatened Animals. IUCN-The World Conservation Union, Gland, Switzerland

Nauwerk, A. (1963) The relations between zooplankton and phytoplankton in lake Erken. Symbolae Botanicae Upsalienses, 17, 1-163.

Provincia de Río Negro (1993) Ley 2056, Arts. 8, 9 and 12. Disposición Subdirección de Fauna 05/93: Especies protegidas de la Fauna Silvestre Provincial.

Reynolds, C.S. (1984) Phytoplankton periodicity: the interactions of form, function and environmental variability. Freshwater Biology, 14, 111-142.

Secretaría de Agricultura y Ganadería (1983) Resolución 144 83. Boletín Oficial $8 / 4 / 83$ and $2 / 5 / 83$, pp. 1-33

Trevisan, R. (1979) Nota sull'uso dei volumi algali per la stima della biomassa. Rivista di Idrobiologia, 17(3), 345-357.

Úbeda, C.A., Grigera, D. \& Reca, A.R. (1994) Estado de conservación de la herpetofauna del Parque y Reserva Nacional Nahuel Huapi. Cuadernos de Herpetología, 8(1), 155-163.

Úbeda, C.A. \& Grigera, D. (eds) (1995) Recalificación del Estado de Conservación de la Fauna Silvestre Argentina. Región Patagónica, pp. 95. Secretaría de Recursos Naturales y Ambiente Humano y Consejo Asesor Regional Patagónico de la Fauna Silvestre, Buenos Aires.

Vollenweider, R.A. (1968) Scientific fundamentals of the eutrophication of lakes and flowing waters, with particular reference to nitrogen and phosphorus as factors in eutrophication, pp. 189. Organization for Economic Cooperation and Development (OECD).

Wake, D.B. \& Morowitz, H.J. (1991) Declining amphibian populations - a global phenomenon? Findings and recommendations. Workshop sponsored by the Board on Biology, National Research Council of the USA. Alytes, 9(2), $33-42$.

Wetzel, R.G. (1975) Limnology, pp. 743. Saunders, Philadelphia, PA.

Zagarese, H.E., Feldman, M. \& Williamson, C.E. (1997) UV-B induced damage and photoreactivation in three species of Boeckella (Copepoda, Calanoida). Journal of Plankton Research, 19, 357-367.

\section{Biosketches}

Carmen Úbeda works at the Universidad Nacional del Comahue in Argentina. Her primary research interests are focused on the biodiversity, biology, distribution and conservation of the amphibians of Patagonian temperate forests. 